\title{
Influence of Trifloxystrobin on Primary Inoculum and Progression of Scab Epidemics on Stone Fruit
}

N. Lalancette, K. A. McFarland, and A. L. Burnett, Rutgers University, Department of Plant Biology and Pathology, Rutgers Agricultural Research and Extension Center, Bridgeton, NJ 08302-5919

\begin{abstract}
Lalancette, N., McFarland, K. A., and Burnett, A. L. 2015. Influence of trifloxystrobin on primary inoculum and progression of scab epidemics on stone fruit. Plant Dis. 99:467-473.

The ability of the QoI fungicide trifloxystrobin to reduce production of conidia by Fusicladium carpophilum on twig lesions was quantitatively assessed over a 3-year period from 2005 through 2007. Four annual treatment programs, consisting of two consecutive trifloxystrobin applications at pink + bloom, bloom + petal fall, and petal fall + shuck-split, plus a single application timing at petal fall, were examined in a 'Redgold' nectarine orchard harboring high levels of overwintering scab lesions. Sporulation potential, the ability of twig lesions to produce conidia under optimum environmental conditions, was subsequently assessed five to six times during each spring and early summer. In each year of the study, all four treatments significantly reduced the area under the sporulation curve or peak sporulation. The petal fall + shuck-split program provided the greatest antisporulant activity, reducing conidia production at peak sporulation by 82 to $92 \%$. Furthermore, examination of results over the 3-year period showed that the programs significantly

slowed the annual rate of increase in peak sporulation; however, none of the programs completely halted or caused a decline in the annual rate. Although no fungicide was applied after the treatment programs, results from fruit disease assessments showed that these programs, applied as much as 3 months earlier, significantly reduced disease incidence and, in particular, disease severity. A comparison of four QoI fungicides in 2008 indicated that trifloxystrobin and azoxystrobin provided the most control of fruit scab, while pyraclostrobin + boscalid and fluoxastrobin yielded minimal or no benefit. Results of this study demonstrate that certain QoI fungicides, in particular trifloxystrobin and azoxystrobin, can probably improve the efficacy of current protectant programs used for peach scab control by providing season-long control of $F$. carpophilum sporulation on twig lesions. Such program enhancement may be critical when orchards have high inoculum levels and/or environmental conditions are very favorable to disease development.
\end{abstract}

Peach and nectarine scab is caused by the plant pathogenic fungus Fusicladium carpophilum (Thuem.) Oudem. (syn. Cladosporium carpophilum, Fusicladosporium carpophilum) (13). The disease occurs wherever these crops are grown in warm, humid climates accompanied by frequent rainfall $(1,4)$. Thus, in the United States, scab is most prevalent and problematic in the eastern half of the country. The role of the teleomorph stage Venturia carpophila in the disease cycle and epidemiology of peach scab is unknown.

F. carpophilum overwinters as mycelia in lesions on fruit-bearing 1 -year-old twigs $(4,5)$. Conidial production on these lesions commences at bloom in spring and continues for approximately 10 weeks, tapering off during early to midsummer $(2,11,12,15)$. These asexual spores, which are produced on olive-colored tufts of conidiophores, act as the primary inoculum for the ensuing epidemic. Dispersal of conidia occurs during rainy periods to newly formed fruit, current season vegetative shoots, and foliage (5). Research on inoculum dispersal mechanisms demonstrated that fruit infection results primarily from rain-splash and twig runoff (10).

New lesions appear on current season twigs at about the same time as disease is first observed on fruit. Most of these lesions do not completely develop and become infectious until the following year $(5,11)$. Some new twig lesions may produce conidia later in the season, but this inoculum is of little importance in the disease cycle (1). Foliar infections are not common, and produce few conidia later in the season. In general, secondary inoculum from fruit infections also

Current address of A. L. Burnett: FMC Corporation, 701 PrincetonSouth Corporate Center, Ewing, NJ 08628.

Corresponding author: N. Lalancette; E-mail: lalancette@ njaes.rutgers.edu

Accepted for publication 3 October 2014.

http://dx.doi.org/10.1094/PDIS-05-14-0502-RE

(C) 2015 The American Phytopathological Society does not contribute significantly to epidemic development since the latent period is quite long, ranging from 42 to 77 days (4). Such secondary cycles would be most important on late cultivars that sustained early fruit infections. Thus, the majority of inoculum for the current season epidemic originates from overwintering lesions on 1 -year-old twigs. The pathogen does not survive on 2-year-old or older wood.

Given the above, twig lesions are an important inoculum source for both the initiation and propagation of scab epidemics. Any reduction in this primary inoculum should theoretically reduce the severity of the epidemic. Nevertheless, current disease control strategy is primarily focused on prevention of fruit and shoot infection with protectant fungicides (4). Management of scab, therefore, could potentially be improved by employing measures to reduce inoculum production as well as preventing infection. An earlier study showed that applications of the quinone outside inhibitor (QoI) fungicide azoxystrobin during bloom and shuck-split significantly reduced sporulation on overwintering twig lesions (2). A subsequent study demonstrated that the QoI fungicide trifloxystrobin may provide even greater antisporulant activity $(9,12)$. These results suggest that early applications of the QoI fungicides in conjunction with subsequent protectant programs may provide enhanced disease control. This greater level of control would be particularly important when environmental conditions favor scab development and/or when unusually high numbers of overwintering twig lesions are present.

The main objective of this study was to quantify the ability of trifloxystrobin applications to reduce primary inoculum production on overwintering twig lesions. Specifically, different application timings of trifloxystrobin during bloom and shuck-split were compared to determine which program was most effective at reducing sporulation and fruit infection. A second objective was to examine the ability of these fungicide programs to reduce twig lesion development over a 3-year period. Any gradual, long-term reduction in shoot infection, and therefore subsequent primary inoculum production, would augment and compound the effectiveness of the overall control program. A third objective was to compare four different QoI fungicides for 
their ability to manage fruit scab incidence and severity. Finally, results of sequential sporulation assessments on nontreated twigs should provide data for creation of seasonal sporulation curves. These graphs, which indicate availability of inoculum for infection, have not been constructed for the southern New Jersey or midAtlantic fruit growing region. Partial results of this study were reported previously $(7,8)$.

\section{Materials and Methods}

Orchard site. The stone fruit orchard chosen for experimentation consisted of a 9-year-old block of 'Redgold' nectarine (Prunus persica var. nucipersica) grafted on 'Lovell' peach rootstock. Trees in the test orchard, located at the Rutgers Agricultural Research and Extension Center, Bridgeton, $\mathrm{NJ}$, were planted at $7.6 \mathrm{~m}$ tree $\times 7.6 \mathrm{~m}$ row spacing. During the season prior to initiation of the study in 2005, the orchard had received minimal fungicide applications, thereby allowing a buildup of scab lesions on twigs. Standard practices for tree management, insect control, and weed control were followed throughout the study (3).

Experimental design. In all three years of the study (2005 through 2007), trifloxystrobin fungicide treatments were arranged in a randomized complete block design with three blocks. Since rain-splashed inoculum could potentially be transported by strong winds, the longer dimensions of each replicate block were oriented perpendicular to the prevailing wind. Individual treatment plots within each block consisted of nine trees in a square $3 \times 3$ tree formation. Each plot was immediately adjacent on all sides to neighboring plots; that is, nontreated buffer trees were not used between treatment plots. To examine the cumulative effect of each treatment program, tree plots received the same treatment in each consecutive year of the study. No other fungicides were applied.

Treatments. A total of four trifloxystrobin treatments were applied. Three of these treatments consisted of two sequential applications during the bloom period at the following phenological timings: (i) pink and full bloom $(\mathrm{P}+\mathrm{B})$; (ii) full bloom and petal fall $(\mathrm{B}+\mathrm{PF})$; and (iii) petal fall and early shuck-split $(\mathrm{PF}+\mathrm{SS})$. The fourth treatment, which was replicated in only two of the three blocks, consisted of a single application at petal fall (PF). The pink, full bloom, petal fall, and early shuck-split timings were defined as 5\% bloom, 75 to $100 \%$ bloom, 75 to $100 \%$ petal fall, and 5\% shuck-split, respectively. The application dates for these timings were April 17 and 22 and May 2 and 9 in 2005; April 3, 11, and 21 and May 2 in 2006; and April 3 and 25 and May 4 and 14 in 2007.

All treatment applications were applied at the rate of $140.1 \mathrm{~g}$ trifloxystrobin per hectare (Flint 50WG; Bayer CropScience, Research Triangle Park, NC), which was the maximum rate labeled for any crop. Sprays were applied to each plot by a Rears Pak-Blast-Plot airblast sprayer (Rears Manufacturing, Eugene, OR) at 935 liters/ha, $3.4 \mathrm{~km} / \mathrm{h}$ tractor speed, and $690 \mathrm{kPa}$ pressure. A nontreated control treatment was included to indicate the level of disease pressure.

Sporulation assessment. In 2005 and 2006, inoculum production on overwintering twig lesions in all plots was assessed five and six times, respectively. These assessments were performed throughout the sporulation periods from early May through mid-July. In 2007, six successive primary inoculum assessments were also performed, but only for the nontreated control; all remaining treatments were assessed only once at peak sporulation in late May. For the purposes of this study, peak sporulation was defined as the time or assessment at which maximum sporulation was observed.

During each assessment, a total of 10 twigs in 2005 or 16 twigs in 2006 and 2007 bearing overwintering scab lesions were pruned from the outer eight trees in each plot. Twigs were cut to a length of $15 \mathrm{~cm}$, measured from the distal growing tip backward. After leaf removal, the twigs were washed in running tap water for $30 \mathrm{~s}$ to remove debris and any previously produced spores. Twig samples were then placed in plastic trays $(18 \times 14 \times 3 \mathrm{~cm}$ deep) maintained at high $(>95 \%)$ relative humidity by lining the bottom with moist paper towel and covering the tray with a tight-fitting lid. Twigs were placed across two $8 \mathrm{~mm}$ diameter plastic tubes to elevate them above the moistened paper towel. To further ensure a high humidity level throughout the tray volume, the sides and bottom of lid were atomized with deionized water to produce a fine layer of water beads. Trays were then placed in an unlit incubator for $24 \mathrm{~h}$ at $25^{\circ} \mathrm{C}$. Water condensation on the clear plastic sides of the trays was monitored to ensure maintenance of a near-saturated atmosphere within the tray.

After completion of the incubation period, twigs from each sample were individually spray washed using a DeVilbiss atomizer set at $52 \mathrm{kPa}$ (DeVilbiss Health Care, Inc., Somerset, PA). The atomizer was moved both up and down the length of the twig four times (once per quarter turn). Spores from all 10 or 16 twigs in each sample were bulk collected in the same flask. After agitation, the concentration of conidia in the suspension was estimated by averaging 10 hemacytometer chamber counts performed with the aid of a compound microscope $(200 x)$. From these recorded data, the number of conidia per centimeter of twig length was calculated as the sporulation dependent variable.

Twig lesion assessment. In addition to infecting fruit, conidia from overwintering twig lesions also infect new shoots produced during the current season (4). However, these newly formed overwintering lesions do not become completely visible until the following spring. Thus, to examine the fungicide effect on twig disease development, shoots were assessed after a 1-year delay, in 2006 and 2007.

At the time of peak sporulation in each year (days 159 and 150 in 2006 and 2007, respectively), two twigs were harvested from each of the outer eight trees in each plot, for a total of 16 twigs per replicate. The total number of lesions on each twig was counted using a dissecting microscope at low magnification. The length of each twig was scanned three times, rotating the twig by one-third between scans. The green underside of the twigs served as an initial reference point. From these data, the average number of lesions per twig was calculated as the dependent variable.

Fruit disease assessment. In each year of the study, fruit were assessed for scab development three times at 2 -week intervals. Since the incubation period on fruit is quite long, ranging from 42 to 77 days (4), these assessments began in mid-July and ended in mid-August. A total of 25 fruit were arbitrarily selected from the center tree within each plot. No twigs were removed from this tree for assessment of primary inoculum. The total number of scab lesions were counted and recorded for each fruit. From these data, disease incidence was expressed as percent infected fruit and disease severity as lesion density or number of lesions per fruit.

Fungicide comparison. In 2008, a follow-up study was conducted in the same 'Redgold' nectarine block to compare four QoI fungicides for their ability to manage fruit scab development. The experimental design was a randomized complete block with four blocks. Unlike the main study, treatment plots consisted of single trees that were surrounded on all sides by nonsprayed buffer trees.

The fungicides examined in the study, which were applied only at petal fall and early shuck split, were trifloxystrobin at $138.8 \mathrm{~g} / \mathrm{ha}$ (Gem 500SC; Bayer CropScience); azoxystrobin at $282.2 \mathrm{~g} / \mathrm{ha}$ (Abound 2.08F; Syngenta Crop Protection, Greensboro, NC); pyraclostrobin at $130.0 \mathrm{~g} / \mathrm{ha}+$ boscalid at $273.5 \mathrm{~g} / \mathrm{ha}$ (Pristine 38WG; BASF Corp., Research Triangle Park, NC); and fluoxastrobin at $199.6 \mathrm{~g} / \mathrm{ha}$ (Evito 480SC; Arysta LifeScience, Cary, NC). These rates were the maximum labeled rates for stone fruit (Gem, Abound, and Pristine) or vegetables (Evito). Note that the maximum rate of Gem 500SC, the current formulation of trifloxystrobin registered for use on stone fruit, provided a slightly lower amount of active ingredient than the maximum rate of Flint 50WG used in the main study. Sprays were applied using the same equipment and methodology as in the main study. A nontreated control treatment was included to indicate the level of disease pressure. Fruit scab development was evaluated on July 15 by examining 50 fruit arbitrarily picked from each treatment tree. Disease incidence and percent fruit having 1 to 10 lesions, 11 to 50 lesions, and $>50$ lesions were calculated as the dependent variables.

Statistical analysis. Given the recorded data on twig lesion spore production over time, the areas under the sporulation curves (AUSC) were calculated for each treatment plot in 2005 and 2006. Since the time periods for these curves were different in each year, the areas were adjusted or standardized by dividing the values by the total number of days between the first and last assessment. The pooled 
adjusted AUSCs for 2005 and 2006, along with the peak sporulation data observed in 2007, were then subjected to an analysis of variance (ANOVA) using the general linear models (GLM) procedure of the Statistical Analysis System v9.3 (SAS Institute, Cary, NC). Treatment mean comparisons were performed using the Waller-Duncan $K$-ratio $t$ test

To examine the cumulative effect of annual fungicide applications during bloom on seasonal sporulation capacity, the peak sporulation values observed in each year were plotted against year. The time of peak sporulation was defined as the assessment day with the highest sporulation for nontreated twig lesions. Linear and exponential models were then fit to each treatment curve using the REG procedure of SAS. The slopes of each curve, which represent the annual rate of increase in peak sporulation, were then subjected to an ANOVA using the GLM procedure of SAS; slope mean comparisons were performed using the Waller-Duncan $K$-ratio $t$ test.

In a similar fashion, twig lesion density data from 2006 and 2007 and areas under the disease incidence (AUDIC) and lesion density (AULDC) curves for fruit infection in all three years were subjected to an ANOVA using the GLM procedure of SAS. As with the sporulation curves, areas for the fruit disease progress curves were adjusted or standardized by dividing the areas by the durations of the assessment periods. Data from the QoI fungicide comparison study conducted in 2008 were also subjected to an ANOVA using the GLM procedure of SAS. Individual treatment means in each analyses were compared using the Waller-Duncan $K$-ratio $t$ test. Finally, in each of the above analyses, arcsin and log transformations were performed as needed for proportions and lesion count data, respectively, to correct for departures from the ANOVA assumptions.

\section{Results}

Twig lesion sporulation. Graphs of spore production over time from nontreated twig lesions revealed that peak sporulation in southern New Jersey occurred in late May to early June, between days 150 and 159 (Fig. 1). In terms of tree phenology, this timing corresponds to the period between 35 to 58 days after full bloom. After attaining this maximum level, spore production diminished over the next 40 to 50 days. By the final assessment in mid-July (days 189 to 200), sporulation was only 6.5 to $11.6 \%$ of its peak value. In this study, sporulation assessments were not conducted early enough to detect the time at which lesions first began producing conidia. However, reasonably high levels of spore numbers were observed during the first assessments on days 140 and 131 in 2005 and 2006, respectively (Fig. 1). These results indicated that inoculum was most likely available at the time of early (5\%) shuck-split, which occurred only 11 and 9 days previously on days 129 and 122, respectively. In 2007, 5\% shuck-split occurred late on day 134, at which time very high levels of inoculum had already been observed in the orchard (Fig. 1).

The results of the ANOVA of the combined AUSC data for 2005 and 2006 indicated that the fungicide treatment main effect was highly significant $(P=0.0001)$, while the year $(P=0.27)$ and block $(P=0.55)$ main effects were not significant. Furthermore, since the year $\times$ treatment interaction was also not significant $(P=0.14)$, differences among treatments were consistent across both years. Thus, a single analysis was performed on the pooled AUSC data, and comparison of the specific treatment means revealed that all four fungicide programs significantly lowered sporulation (Table 1). Reductions in the AUSC ranged from $64.1 \%$ for the PF treatment in 2005 to $92.2 \%$ for the $\mathrm{PF}+\mathrm{SS}$ treatment in 2006. Similar results were obtained from analysis of the peak sporulation data obtained in 2007 (Table 1).

Cumulative effect on sporulation. The overall level of sporulation by the pathogen on nontreated twig lesions, as indicated by the amplitude of the sporulation curves, increased incrementally each year of the study (Fig. 1). This trend indicates a buildup of disease, and therefore primary inoculum, on nontreated control trees. A graph of annual peak sporulation over time (years) for each treatment showed a fairly sharp increase in inoculum production for nontreated twig lesions and somewhat slower increases for fungicide-treated lesions (Fig. 2). A fit of the exponential model to these curves did not provide a significant improvement over a straight line fit. Consequently, all subsequent analyses were performed using a linear model. Comparison of model slopes showed that all four fungicide treatment programs significantly reduced the annual rate of increase in seasonal sporulation capacity (Table 2). However, for three of the four treatments, the slopes were significantly different from zero, thereby indicating that the fungicide only slowed and did not completely halt the rate of increase. The slope of the PF treatment curve was not significantly different from zero, but this outcome may have resulted from a considerably higher amount of variation in the data, as indicated by a relative variation of $76.4 \%$ (Table 2).

Twig lesion density. Counts of overwintering twig lesions in 2006 and 2007, which resulted from twig infections during the previous year, showed that early season trifloxystrobin applications can reduce the severity of twig infection (Table 3). All three two-application programs applied in 2005 significantly reduced the density of overwintering twig lesions observed in 2006. The degree of these reductions ranged from $50.2 \%$ for the $\mathrm{PF}+\mathrm{SS}$ program to $70.7 \%$ for the $\mathrm{P}+\mathrm{B}$ program. In 2007, twigs receiving the same three treatments continued to

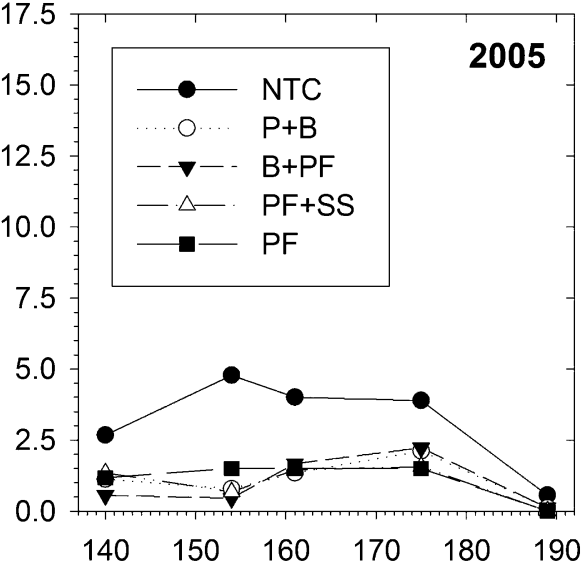

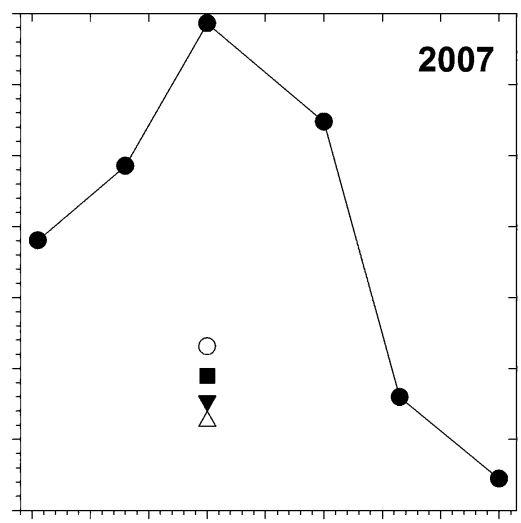

120130140150160170180190200

\section{Day of year}

Fig. 1. Ability of nontreated control (NTC) and fungicide-treated overwintering scab twig lesions caused by Fusicladium carpophilum to produce conidia during the spring and early summer sporulation periods of 2005, 2006, and 2007 in a 'Redgold' nectarine orchard. Treatments consisted of trifloxystrobin applied at pink and bloom ( $P+B$ ), bloom and petal fall $(B+P F)$, petal fall and shuck-split (PF+SS), and petal fall (PF). Data points are based on assessments of sporulation on 20 to 48 detached twigs under optimum environmental conditions. In 2007, fungicide treatments were only assessed at the time of peak sporulation indicated by the NTC. 
have lower lesion densities than observed on control twigs, but only those twigs treated with the $\mathrm{PF}+\mathrm{SS}$ program had a significantly lower lesion density (Table 3).

Fruit disease development. Disease pressure on fruit was very high throughout the study. Maximum disease severities of 654 , 439, and 219 lesions per fruit were observed on nontreated fruit during 2005, 2006, and 2007, respectively (Fig. 3). Given this intense disease pressure, the incidence of fruit infection ranged from 95 to $100 \%$ for all three assessments in each year of the study. Under these conditions, the single application PF treatment, and the earliest twoapplication treatment, $\mathrm{P}+\mathrm{B}$, provided minimal control of fruit disease incidence and severity (Fig. 3). However, the B+PF and PF+SS treatment programs demonstrated a greater ability to suppress the fruit scab epidemics, particularly for the lesion density dependent variable.

Results of the ANOVA of the combined adjusted AUDIC data for 2005, 2006, and 2007 indicated that the fungicide treatment and year main effects were highly significant $(P<0.0001$ and $P=0.0021$, respectively), while the block $(P=0.59)$ main effect was not significant. Results from the ANOVA of the combined adjusted AULDC data also revealed a significant fungicide treatment main effect $(P=0.0020)$, while the year $(P=0.0850)$ and block $(P=0.17)$ main effects were not significant. For both dependent variables, however, the year $\times$ treatment interactions were not significant $(P=0.44$ for AUDIC; $P=0.99$ for AULDC), thereby indicating that specific treatment means could be compared using a single analysis on the pooled data sets.

Analysis of the pooled data showed that all three two-application fungicide treatment programs significantly reduced AUDIC, although the reductions were not large, ranging from only $6 \%$ for the $\mathrm{P}+\mathrm{B}$ treatment to $19 \%$ for $\mathrm{PF}+\mathrm{SS}$ (Table 4). In contrast, significant reductions in lesion densities were observed for all four treatments. On average across all three years of the study, adjusted AULDC values were reduced by $55,65,79$, and $87 \%$ for the $\mathrm{PF}, \mathrm{P}+\mathrm{B}, \mathrm{B}+\mathrm{PF}$, and $\mathrm{PF}+\mathrm{SS}$ treatments, respectively. At the time of the last assessment in 2007, nontreated fruit had an average 129 lesions, while fruit that received the PF+SS program had only 9.2 lesions (Fig. 3). This $93 \%$ reduction in lesion density occurred even though the PF and SS applications had been applied 102 and 92 days earlier, respectively.

Table 1. Effect of trifloxystrobin applications during the bloom period on subsequent sporulation of Fusicladium carpophilum in scab twig lesions in a 'Redgold' nectarine orchard in 2005, 2006, and 2007

\begin{tabular}{|c|c|c|c|c|c|c|c|}
\hline \multicolumn{4}{|c|}{ Fungicide application timingw } & \multicolumn{3}{|c|}{$\operatorname{AUSC}(\operatorname{adj})^{x}($ conidia $/$ cm twig $) \times$ day } & \multirow{2}{*}{$\frac{\text { Peak sporulation }^{\mathrm{y}}\left(\text { conidia } / \mathrm{cm} \text { twig) }^{2007^{\mathrm{z}}}\right.}{2}$} \\
\hline Pink & Bloom & Petal fall & Shuck split & 2005 & 2006 & Pooled $^{z}$ & \\
\hline \multirow{5}{*}{$X$} & & ed control & & 3,452 & 5,556 & $4,504 \mathrm{a}$ & $17,148 \mathrm{a}$ \\
\hline & & $\mathrm{X}$ & & 1,238 & 2,932 & $2,085 \mathrm{~b}$ & $4,740 \mathrm{~b}$ \\
\hline & $\mathrm{X}$ & & & 1,230 & 1,033 & $1,132 \mathrm{~b}$ & $5,774 \mathrm{~b}$ \\
\hline & $X$ & $\mathrm{X}$ & & 1,182 & 627 & $905 \mathrm{~b}$ & $3,851 \mathrm{~b}$ \\
\hline & & $\mathrm{X}$ & $\mathrm{X}$ & 1,087 & 433 & $760 \mathrm{~b}$ & $3,141 \mathrm{~b}$ \\
\hline
\end{tabular}

${ }^{\mathrm{w}}$ Application timing based on tree phenology: Pink $=5 \%$ bloom; bloom $=75$ to $100 \%$ full bloom; petal fall $=75$ to $100 \%$ petal fall; and shuck split $=5 \%$ calyx split, exposing fruit surface.

x Area under sporulation curves (AUSC) based on five and six assessments in 2005 and 2006, respectively (Fig. 1); areas adjusted for differences in duration of assessed sporulation periods (49 days in 2005; 69 days in 2006), where AUSC (adj) = AUSC / duration in days.

y In 2007, only a single sporulation assessment was performed on day 150, the time of peak sporulation for nontreated twigs (Fig. 1).

${ }^{\mathrm{z}}$ Means in the same column followed by the same letter are not significantly different according to the Waller-Duncan $K$-ratio $t$ test $(K$-ratio $=100 ; P \leq 0.05)$.

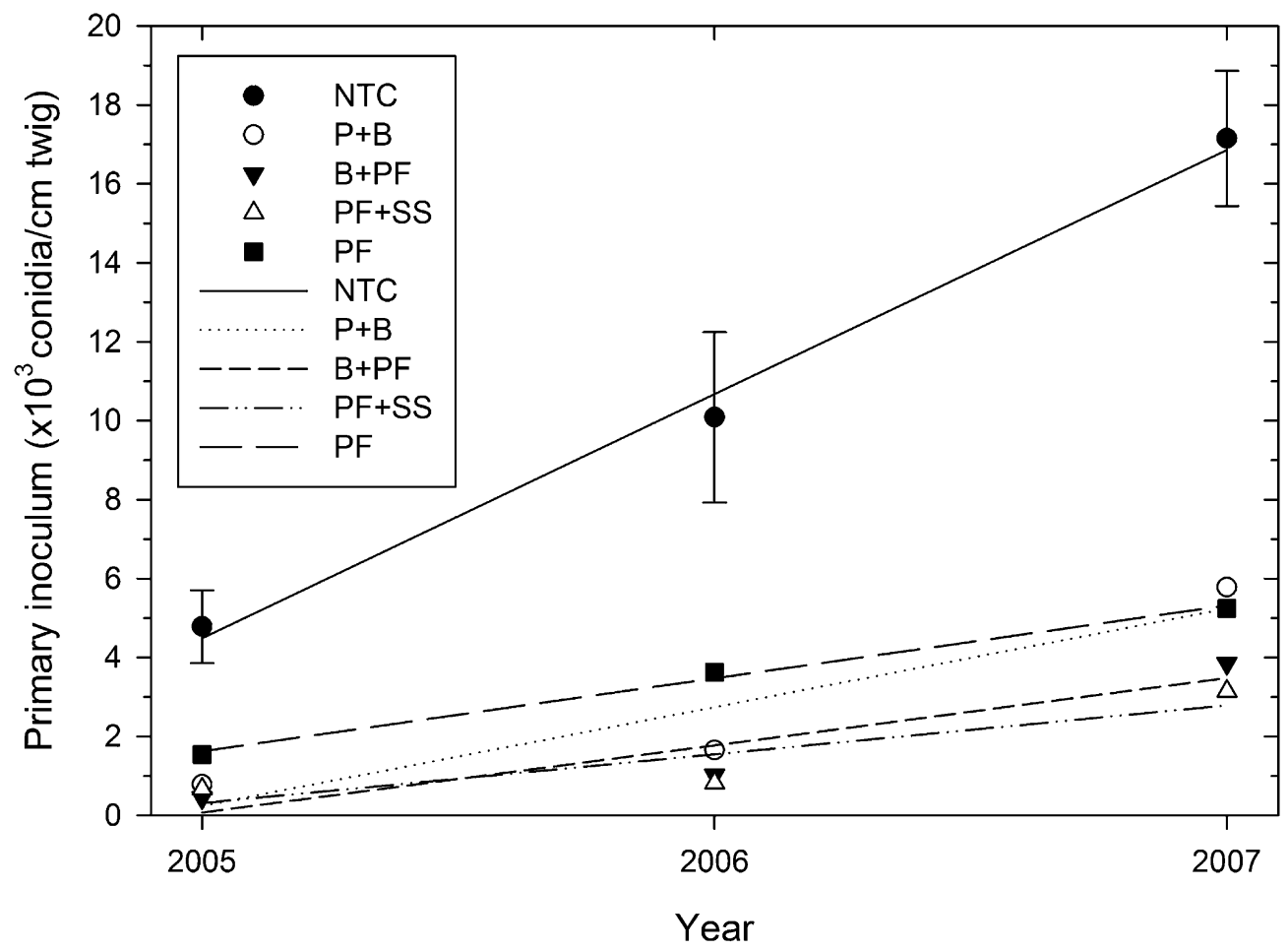

Fig. 2. Change in annual peak sporulation across all three years of the study for nontreated control (NTC) and fungicide-treated overwintering scab twig lesions caused by Fusicladium carpophilum in a 'Redgold' nectarine orchard. Treatments consisted of trifloxystrobin applied at pink and bloom $(P+B)$, bloom and petal fall (B+PF), petal fall and shuck-split (PF+SS), and petal fall (PF). The same treatments were applied to the same plots each year. Data points are peak or maximum levels of sporulation observed in each year and are based on assessments of sporulation on 20 to 48 detached twigs under optimum environmental conditions. Standard error bars are shown for the NTC. Lines are predicted values from linear regression models fit to the data (Table 2). 
Fungicide comparison. In contrast to the fruit disease results from the main study, no significant differences in disease incidence were observed for any of the QoI fungicide treatments in 2008 (Table 5). However, trifloxystrobin and azoxystrobin significantly decreased the number of fruit with $>50$ lesions by 47 and $40 \%$, respectively, while significantly increasing the number of fruit in the less severe 11 to 50 lesion/fruit category. Fluoxastrobin and pyraclostrobin + boscalid had little or no effect on fruit scab severity.

\section{Discussion}

Application of trifloxystrobin fungicide to nectarine trees during the bloom and early shuck-split phenological stages reduced sporulation of overwintering scab twig lesions in each year of the study. Based on analyses of AUSCs and peak sporulation data, all four fungicide treatment programs significantly lowered conidia production. Although no statistical differences were observed among these programs, the two-application $\mathrm{PF}+\mathrm{SS}$ treatment consistently provided the highest level of antisporulant activity in each of the three years. The reduction in conidia production at peak sporulation for this treatment ranged from $82 \%$ in 2007 to $92 \%$ in 2006 . In contrast, the singleapplication PF treatment exhibited lower antisporulant activity, providing a 57 to $72 \%$ reduction in conidia production at peak sporulation.

Results from this experiment agree with those obtained from an earlier study examining the antisporulant activity of the QoI fungicide azoxystrobin against peach scab (2). In this earlier study, single applications of azoxystrobin were applied at bloom, petal fall, and shuck-split, followed by five to six sulfur applications extending into the cover spray period. Across the various disease assessments, the reduction in conidia production ranged from 51 to $73 \%$ for the bloom treatment; 52 to $79 \%$ for the petal fall treatment; and 41 to $76 \%$ for the shuck-split treatment. These levels of inhibition agree closely with those observed in our study for the single spray application at petal fall. However, as might be expected, when two trifloxystrobin applications were applied in our study, the level of antisporulant activity exceeded that observed for the single application azoxystrobin treatments in the earlier experiment.

Trifloxystrobin applications during bloom and shuck-split resulted in an inhibition of conidia production that lasted for the entire sporulation period. That is, sporulation levels on treated lesions were not observed to recover to levels of nontreated lesions, even as many as 68 days after the final shuck-split spray. This extended activity suggests that trifloxystrobin may be providing eradicant as well as antisporulant activity. During the period between twig infection in the first year and sporulation in the second year, the pathogen amasses considerable amounts of subcuticular stroma beneath the lesion surface $(5,6)$. These stromatic masses, which can be six to eight cells thick, are initially protected by the plant's cuticle. However, trifloxystrobin is readily absorbed by the plant's waxy layers or cuticle, and from this reservoir slowly moves into the underlying cells (16). Although such movement could result in direct contact with the pathogen's stroma, the concentration of active ingredient is likely to be low. Perhaps more importantly, upon sporulation in the second year, the conidial tufts break through the cuticle, thereby exposing both the spores and stroma to direct contact by the fungicide. In either case, the fungicide may well be preventing sporulation by directly killing the fungal stroma. A histological study is needed to confirm this hypothesis.

The fruit disease assessments clearly indicated that trifloxystrobin applications applied during bloom, as many as 3 months earlier, significantly reduced disease incidence and, in particular, disease severity. Since applications performed during pink, bloom, and petal fall occurred prior to appearance of the fruit, we conclude that inoculum reduction via antisporulant (or eradicant) activity was the primary form of disease control. Similar reductions in fruit disease incidence and severity were observed in the azoxystrobin study (2). However, all fungicide treatments in this latter study received five to six sulfur applications following the azoxystrobin spray at bloom, petal fall, or

Table 2. Cumulative effect of annual applications of trifloxystrobin during the bloom period on the annual rate of increase in peak sporulation of Fusicladium carpophilum in scab twig lesions in a 'Redgold' nectarine orchard between 2005 and 2007

\begin{tabular}{|c|c|c|c|c|c|c|c|c|c|c|}
\hline & & & & \multicolumn{7}{|c|}{ Slope of linear model (conidia / cm twig / year)y } \\
\hline \multicolumn{4}{|c|}{ Fungicide application timing $\mathrm{x}$} & \multicolumn{5}{|c|}{ Parameter estimation $^{\mathrm{z}}$} & \multicolumn{2}{|c|}{$H_{0}:$ slope $=0$} \\
\hline Pink & Bloom & Petal fall & $\overline{\text { Shuck split }}$ & $\mathbf{N}$ & $\mathbf{R}^{2}$ & Estimate & Std. Error & $\overline{\% \mathrm{RV}}$ & $\overline{t \text {-value }}$ & $P>t$ \\
\hline \multirow{5}{*}{$\mathrm{X}$} & \multicolumn{3}{|c|}{ Nontreated control } & 9 & 0.53 & 6,185 a & 2,205 & 35.7 & 2.80 & 0.0263 \\
\hline & \multicolumn{3}{|c|}{$\mathrm{X}$} & 6 & 0.30 & $1,620 \mathrm{~b}$ & 1,238 & 76.4 & 1.31 & 0.2607 \\
\hline & $\mathrm{X}$ & & & 9 & 0.73 & $2,498 \mathrm{~b}$ & 569 & 22.8 & 4.39 & 0.0032 \\
\hline & \multirow[t]{2}{*}{$\mathrm{X}$} & $\mathrm{X}$ & & 9 & 0.61 & $1,703 \mathrm{~b}$ & 520 & 30.5 & 3.28 & 0.0135 \\
\hline & & $X$ & $X$ & 9 & 0.69 & $1,237 \mathrm{~b}$ & 315 & 25.5 & 3.93 & 0.0057 \\
\hline
\end{tabular}

${ }^{\times}$Application timing based on tree phenology: Pink $=5 \%$ bloom; bloom $=75$ to $100 \%$ full bloom; petal fall $=75$ to $100 \%$ petal fall; and shuck split $=5 \%$ calyx split, exposing fruit surface.

${ }^{y}$ Linear model fit to peak sporulation as a function of year (Fig. 2); the time of peak sporulation (days 154, 159, and 150 in 2005 through 2007 , respectively) was defined as the assessment day with the highest sporulation for nontreated twig lesions (Fig. 1).

${ }^{\mathrm{z}}$ Slope parameter estimates in the same column followed by the same letter are not significantly different according to the Waller-Duncan $K$-ratio $t$ test $(K$-ratio $=$ $100 ; P \leq 0.05) ; \% \mathrm{RV}$ is percent relative variation $=($ std. error $/$ estimate $) \times 100$.

Table 3. Effect of trifloxystrobin applications during the bloom period on the density of overwintering scab twig lesions caused by Fusicladium carpophilum in a 'Redgold' nectarine orchard during 2006 and 2007

\begin{tabular}{|c|c|c|c|c|c|c|c|c|c|}
\hline \multirow[b]{3}{*}{ Pink } & \multirow{2}{*}{\multicolumn{3}{|c|}{ Fungicide application timing ${ }^{\mathbf{y}}$}} & \multicolumn{6}{|c|}{ Twig lesion density (lesions / twig) } \\
\hline & & & & \multicolumn{3}{|c|}{$2006^{z}$} & \multicolumn{3}{|c|}{$2007^{z}$} \\
\hline & Bloom & Petal fall & Shuck split & Mean & Std. Error & $\% \mathrm{RV}$ & Mean & Std. Error & $\% \mathrm{RV}$ \\
\hline \multirow{5}{*}{$\mathrm{X}$} & \multicolumn{3}{|c|}{ Nontreated control } & $86.0 \mathrm{a}$ & 8.90 & 10.3 & $70.9 \mathrm{a}$ & 4.66 & 6.6 \\
\hline & \multicolumn{3}{|c|}{$\mathrm{X}$} & $85.7 \mathrm{a}$ & 17.84 & 20.8 & $70.2 \mathrm{a}$ & 1.53 & 2.2 \\
\hline & $\mathrm{X}$ & & & $25.2 \mathrm{~b}$ & 4.46 & 17.7 & $57.7 \mathrm{ab}$ & 8.65 & 15.0 \\
\hline & \multirow[t]{2}{*}{$\mathrm{X}$} & $X$ & & $32.8 \mathrm{~b}$ & 5.74 & 17.5 & $61.3 \mathrm{ab}$ & 6.91 & 11.3 \\
\hline & & $\mathrm{X}$ & $\mathrm{X}$ & $42.8 \mathrm{~b}$ & 6.15 & 14.4 & $38.8 \mathrm{~b}$ & 6.43 & 16.6 \\
\hline
\end{tabular}

\footnotetext{
y Application timing based on tree phenology: Pink $=5 \%$ bloom; bloom $=75$ to $100 \%$ full bloom; petal fall $=75$ to $100 \%$ petal fall; and shuck split $=5 \%$ calyx split, exposing fruit surface.

${ }^{\mathrm{z}}$ Means in the same column followed by the same letter are not significantly different according to the Waller-Duncan $K$-ratio $t$ test $(K$-ratio $=100 ; P \leq 0.05)$; $\% \mathrm{RV}$ is percent relative variation $=($ std. error $/$ estimate $) \times 100$.
} 
shuck split. Thus, the degree of fruit disease control exerted by the antisporulant activity of azoxystrobin alone could not be determined.

The greater level of fruit disease control consistently observed for the $\mathrm{PF}+\mathrm{SS}$ treatment was most likely due to protectant as well as antisporulant activity. Unlike the bloom applications, fungicide applied at shuck split would directly contact the fruit. As with most QoI fungicides, the high affinity of trifloxystrobin for the plant surface and absorption into the fruit's waxy cuticle would have aided
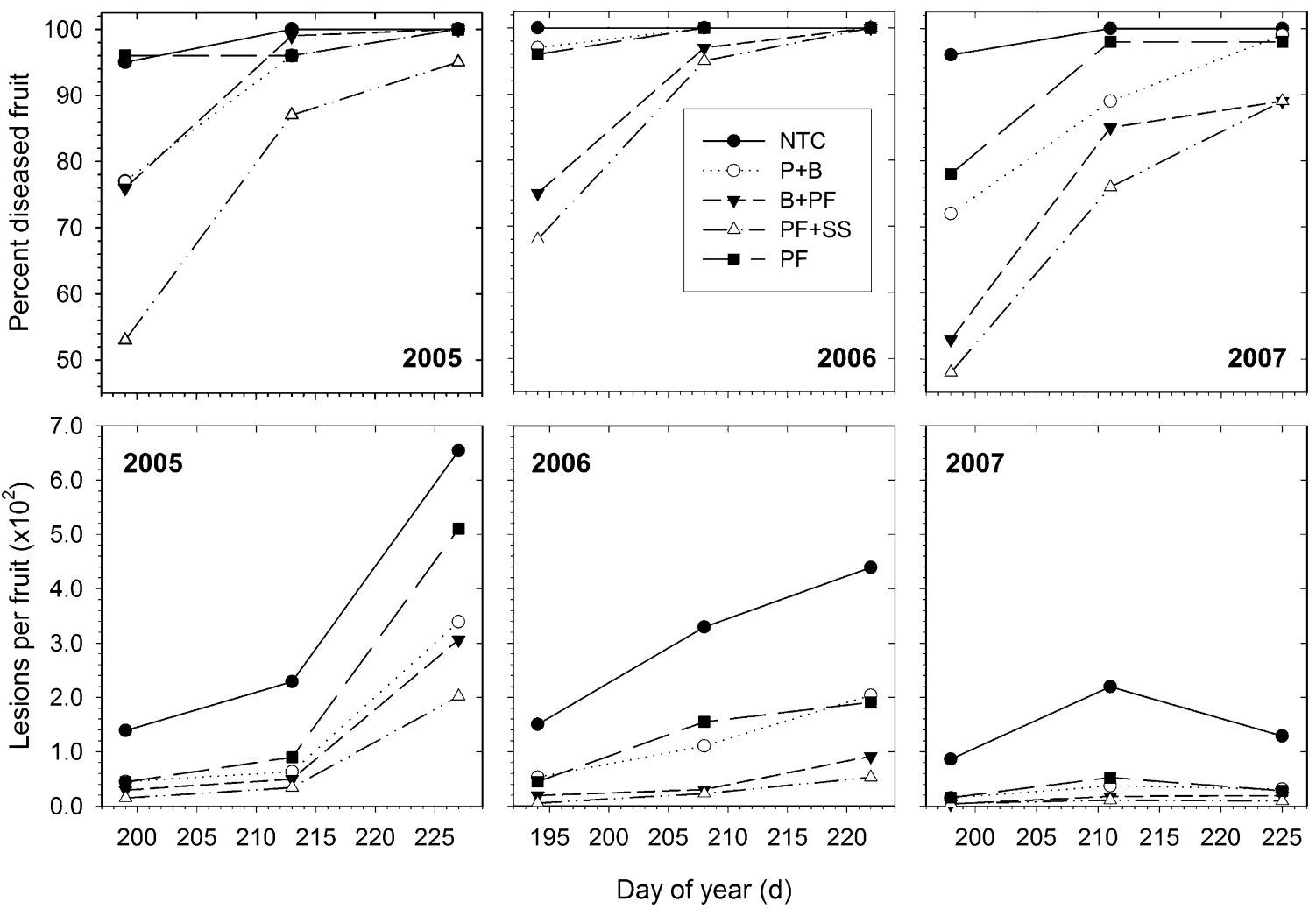

Fig. 3. The influence of early-season trifloxystrobin applications on the progression of fruit scab incidence and severity caused by Fusicladium carpophilum on 'Redgold' nectarine trees. Fungicide treatments were applied at pink and bloom $(\mathrm{P}+\mathrm{B})$, bloom and petal fall $(\mathrm{B}+\mathrm{PF})$, petal fall and shuck-split $(\mathrm{PF}+\mathrm{SS})$, and petal fall $(\mathrm{PF})$; $\mathrm{NTC}=$ nontreated control. The final fungicide applications (at SS) were applied on days 129, 122, and 143 in 2005, 2006, and 2007, respectively. Data points are based on assessment of 50 to 75 fruit.

Table 4. Effect of trifloxystrobin applications during the bloom period on development of fruit scab caused by Fusicladium carpophilum in a 'Redgold' nectarine orchard in 2005, 2006, and 2007

\begin{tabular}{|c|c|c|c|c|c|c|c|c|c|c|c|}
\hline \multicolumn{4}{|c|}{ Fungicide application timing $x$} & \multicolumn{4}{|c|}{ AUDIC $(\text { adj) })^{y}(\%$ diseased fruit $) \times$ day } & \multicolumn{4}{|c|}{ AULDC $(\operatorname{adj})^{y}($ lesions / fruit $) \times$ day } \\
\hline Pink & Bloom & Petal fall & Shuck split & 2005 & 2006 & 2007 & Pooled $^{\mathrm{z}}$ & 2005 & 2006 & 2007 & Pooled $^{\mathbf{2}}$ \\
\hline \multirow{5}{*}{$\mathrm{X}$} & \multicolumn{2}{|c|}{ Nontreated control } & & 98.7 & 100.0 & 99.0 & $99.2 \mathrm{a}$ & 312.6 & 312.0 & 163.9 & $262.8 \mathrm{a}$ \\
\hline & \multirow{2}{*}{\multicolumn{2}{|c|}{$\mathrm{X}$}} & & 97.0 & 99.0 & 93.2 & $96.4 \mathrm{ab}$ & 183.4 & 136.3 & 37.2 & $119.0 \mathrm{~b}$ \\
\hline & & & & 92.3 & 99.3 & 87.6 & $93.1 \mathrm{bc}$ & 127.6 & 119.3 & 30.1 & $92.3 \mathrm{~b}$ \\
\hline & \multirow[t]{2}{*}{$\mathrm{X}$} & $\mathrm{X}$ & & 93.3 & 92.3 & 78.7 & $88.1 \mathrm{c}$ & 108.6 & 42.9 & 14.8 & $55.4 \mathrm{~b}$ \\
\hline & & $\mathrm{X}$ & $\mathrm{X}$ & 80.3 & 89.3 & 72.7 & $80.8 \mathrm{~d}$ & 71.1 & 26.1 & 8.8 & $35.3 \mathrm{~b}$ \\
\hline
\end{tabular}

$\times$ Application timing based on tree phenology: Pink $=5 \%$ bloom; bloom $=75$ to $100 \%$ full bloom; petal fall $=75$ to $100 \%$ petal fall; and shuck split $=5 \%$ calyx split, exposing fruit surface.

y Areas under disease incidence (AUDIC) and lesion density (AULDC) curves for each year based on three assessments (Fig. 3); areas adjusted for difference in duration of assessed periods (28 days in 2005, 2006; 27 days in 2007), where AUDIC (adj) = AUDIC / duration in days, and AULDC (adj) = AULDC / duration in days.

${ }^{\mathrm{z}}$ Means in the same column followed by the same letter are not significantly different according to the Waller-Duncan $K$-ratio $t$ test $(K$-ratio $=100 ; P \leq 0.05)$.

Table 5. Comparison of four QoI fungicides applied at petal fall and shuck split for control of fruit scab caused by Fusicladium carpophilum in a 'Redgold' nectarine orchard in $2008^{z}$

\begin{tabular}{|c|c|c|c|c|}
\hline \multirow[b]{2}{*}{ Fungicide active ingredient } & \multirow[b]{2}{*}{$\%$ Diseased fruit } & \multicolumn{3}{|c|}{$\%$ Fruit with lesions } \\
\hline & & 1 to 10 lesions & 11 to 50 lesions & $>50$ lesions \\
\hline Nontreated & $100.0 \mathrm{a}$ & $0.0 \mathrm{a}$ & $0.5 \mathrm{a}$ & $99.5 \mathrm{a}$ \\
\hline Fluoxastrobin & $100.0 \mathrm{a}$ & $3.5 \mathrm{a}$ & $9.0 \mathrm{ab}$ & $87.5 \mathrm{a}$ \\
\hline Pyraclostrobin + Boscalid & $100.0 \mathrm{a}$ & $1.0 \mathrm{a}$ & $18.0 \mathrm{bc}$ & $81.0 \mathrm{a}$ \\
\hline Azoxystrobin & $99.0 \mathrm{a}$ & $8.5 \mathrm{a}$ & $30.5 \mathrm{~cd}$ & $60.0 \mathrm{~b}$ \\
\hline Trifloxystrobin & $99.5 \mathrm{a}$ & $11.0 \mathrm{a}$ & $36.0 \mathrm{~d}$ & $52.5 \mathrm{~b}$ \\
\hline
\end{tabular}

${ }^{\mathrm{z}}$ All results based on treatment sample size of 200 fruit (50 fruit/tree $\times 4$ replicate trees). Means in the same column followed by the same letter are not significantly different according to the Waller-Duncan $K$-ratio $t$ test $(K$-ratio $=100 ; P \leq 0.05)$. 
in retention of the residue (16). Also, fungicide residues for this treatment would have remained higher for a longer time during the fruit development period given that the shuck split application was the latest of the four application timings. In the earlier azoxystrobin study, fruit disease incidence and severity was also the lowest for the shuck split application timing, although none of the differences in fruit disease levels between treatments were significant (2).

The time of peak sporulation in southern New Jersey, defined in this study as the time of the assessment at which maximum sporulation was observed, occurred between days 150 and 159 (May 30 and June 8). In terms of tree phenology, this period corresponded to 35 to 58 days after full bloom and 16 to 37 days after shuck split. Although the exact time of peak sporulation was not estimated through modeling and interpolation, these phenological periods mostly agree with predictions based on data from many peach cultivars and sites located in the southeastern United States (15). In this latter study, logistic models fit to relative cumulative sporulation data predicted $50 \%$ production (time of peak sporulation) at approximately 39 days after full bloom and 18 days after shuck split.

Results of this study demonstrated that the antisporulant activity of QoI fungicides, in particular trifloxystrobin and azoxystrobin, can contribute significantly to the management of scab on fruit when applied during bloom and early shuck split phenological stages. This outcome agrees fully with the epidemiology of peach scab; conidia produced by overwintering twig lesions provides the major source of inoculum that drives the progression of scab epidemics (1). However, sole use of early season QoI fungicide applications for scab control does not appear to be a viable management strategy since the annual rate of spore production by twig lesions was only slowed and not completely inhibited. Also, the incidence of fruit infection was still relatively high, even though fruit disease severity was reduced considerably. Consequently, early season QoI applications should only be used in conjunction with the standard scab program consisting of protectant fungicide applications during the cover spray period. Furthermore, only one or two applications of QoIs should be applied during bloom or at shuck-split with the remaining applications consisting of a fungicide of different chemistry. This approach is necessary to minimize the risk of resistance development by Monilinia fructicola, the causal agent that infects flowers and causes blossom blight.

Standard scab control programs consisting of protectant fungicides such as captan and sulfur generally provide commercially acceptable control. However, when primary inoculum levels are high and/or environmental conditions are favorable, such programs are often inadequate and the addition of early-season QoI applications should help to maintain control. Early season antisporulant sprays could also be used in conjunction with extended or reduced cover spray programs (14). Nevertheless, since QoIs applied early as antisporulants will exert a strong selection pressure toward resistant strains of $F$. carpophilum, the continued use of protectants provides an important strategy for resistance management.

\section{Acknowledgments}

This research was funded in part by the New Jersey Agricultural Experiment Station. The authors wish to thank Elspeth Murday for her technical assistance in the study.

\section{Literature Cited}

1. Anderson, H. W. 1956. Diseases of Fruit Crops. McGraw-Hill Book Co., New York.

2. Cook, M. J., and Scherm, H. 1999. Antisporulant activity of earlyseason fungicide sprays against peach scab, 1998. Fungic. Nematic. Tests 54:53.

3. Drake, D., Hamilton, G. C., Heckman, J. R., Lalancette, N., Majek, B. A., and Shearer, P. W. 2005. The New Jersey Commercial Tree Fruit Production Guide. New Jersey Agric. Exp. Stn., Rutgers Coop. Ext. Bull. E002.

4. Hendrix, F. F., Jr. 1995. Scab. Pages 11-12. in: Compendium of Stone Fruit Diseases. J. M. Ogawa, E. I. Zehr, G. W. Bird, D. F. Ritchie, K. Uriu, and J. K. Uyemoto, eds. American Phytopathological Society, St. Paul, MN

5. Keitt, G. W. 1917. Peach scab and its control. U. S. Dep. Agric. Bull. 395: 1-66.

6. Koch, L. W. 1934. Studies on the overwintering of certain fungi parasitic and saprophytic on fruit trees. Can. J. Res. 11:190-206.

7. Lalancette, N., McFarland, K. A., and Burnett, A. L. 2008. Influence of trifloxystrobin on primary inoculum and progression of scab epidemics on stone fruit. J. Plant Pathol. 90 (S2):141.

8. Lalancette, N., McFarland, K. A., and Burnett, A. L. 2008. Reduction in primary inoculum of Fusicladosporium carpophilum on stone fruit by the QoI fungicide trifloxystrobin. Phytopathology 98:S207.

9. Lalancette, N., Murday, E., and Foster, K. 2005. Efficacy of fungicide applications at bud swell on peach leaf curl and scab development, 2004 Fungic. Nematicide Tests 60:STF015. Online publication.

10. Lan, Z., and Scherm, H. 2003. Moisture sources in relation to conidia dissemination and infection by Cladosporium carpophilum within peach canopies. Phytopathology 93:1581-1586.

11. Lawrence, E. G., Jr., and Zehr, E. I. 1982. Environmental effects on the development and dissemination of Cladosporium carpophilum on peach. Phytopathology 72:773-776.

12. Murday, E., Lalancette, N., and Foster, K. A. 2006. Anti-sporulant activity of trifloxystrobin on nectarine scab twig lesions. Phytopathology 96:S181.

13. Partridge, E. C., and Morgan-Jones, G. 2003. Notes on Hyphomycetes. XC. Fusicladisporum, a new genus for Cladosporium-like anamorphs of Venturia and the pecan scab-inducing fungus. Mycotaxon 85:357-370.

14. Scherm, H., and Savelle, A. T. 2001. Control of peach scab with reduced midseason fungicide programs. Plant Dis. 85:706-712.

15. Scherm, H., Savelle, A. T., Boozer, R. T., and Foshee, W. G. 2008. Seasonal dynamics of conidial production potential of Fusicladium carpophilum on twig lesions in southeastern peach orchards. Plant Dis. 92:47-50.

16. Vincelli, P. 2012. 2002. QoI (Strobilurin) Fungicides: Benefits and Risks. The Plant Health Instructor. 